\title{
More-Than-Human Emotional Communities: British Soldiers and Mules in Second World War Burma
}

DOI:

10.1080/14780038.2020.1744879

\section{Document Version}

Accepted author manuscript

Link to publication record in Manchester Research Explorer

\section{Citation for published version (APA):}

Webb, T., Pearson, C., Summerfield, P., \& Riley, M. (2020). More-Than-Human Emotional Communities: British Soldiers and Mules in Second World War Burma. Cultural and Social History, 1-18.

https://doi.org/10.1080/14780038.2020.1744879

\section{Published in:}

Cultural and Social History

\section{Citing this paper}

Please note that where the full-text provided on Manchester Research Explorer is the Author Accepted Manuscript or Proof version this may differ from the final Published version. If citing, it is advised that you check and use the publisher's definitive version.

\section{General rights}

Copyright and moral rights for the publications made accessible in the Research Explorer are retained by the authors and/or other copyright owners and it is a condition of accessing publications that users recognise and abide by the legal requirements associated with these rights.

\section{Takedown policy}

If you believe that this document breaches copyright please refer to the University of Manchester's Takedown Procedures [http://man.ac.uk/04Y6Bo] or contact uml.scholarlycommunications@manchester.ac.uk providing relevant details, so we can investigate your claim.

\section{OPEN ACCESS}


Thomas Webb, Chris Pearson, Penny Summerfield and Mark Riley

\title{
"More-Than-Human Emotional Communities: British soldiers and mules in Second World War Burma"
}

Accepted for publication in Cultural and Social History, 9 March 2020

\begin{abstract}
This article offers a perspective on the overlooked 'more-than-human' emotional dimensions of the British war effort of 1939 to 1945. We focus on the relationships between British soldiers and their mules in Burma. We argue that the British soldiers who were required to become muleteers, together with their officers and veterinary personnel, formed an 'emotional community' (Rosenwein), based on a shared idea of a close and mutually beneficial relationship between men and mules. The soldiers' ability to connect emotionally with mules helped bind the community together, but the material circumstances of jungle warfare constantly threatened the viability of those bonds.
\end{abstract}

Keywords: mules; British soldiers; Burma; emotional communities; World War Two

British imperial forces were not only fighting against the Japanese army in the jungles of Burma (Myanmar) during the Second World War. ${ }^{1}$ They also fought against nature. In addition to vermin, leeches, mosquitos and monsoons, soldiers faced dense tropical vegetation, hilly terrain, and swamped routes. An article in Picture Post in 1944 described these features as 'incalculable natural enemies'.2 Mules, tough hybrids of donkeys and horses, were enrolled as 'natural allies' in this

\footnotetext{
${ }^{1}$ We use the phrase 'British imperial forces' to reflect the diverse multi-ethnic range of historical actors from the British Empire and Commonwealth who participated in the Second World War. For an overview of the role of the British Empire in the Second World War see A. Jackson, The British Empire and the Second World War (London: Bloomsbury, 2006).

2 Picture Post, 25 November 1944.
} 
fight against the jungle. ${ }^{3} \mathrm{~A}$ photograph of a soldier leading a mule up a muddy track illustrated the Picture Post article. The caption stated 'where a tank is only a nuisance ... a mule can be a treasure. ${ }^{4}$ Mules offered a form of mobility that mechanised transport could not. But their use depended on soldiers learning to control and care for them, even though many had no experience of working with animals. Their deployment also relied on mules becoming capable of enduring long marches and assaults, even though most had no prior experience of battle.

This article explores the interspecies relationships that developed in these demanding conditions, and, specifically, their emotional dynamics. It brings together what John Miller has described as the 'animal turn' in history with the burgeoning field of the history of emotions, in a colonial context. ${ }^{5}$ In addition to recent work in animal history focused on ideas concerning the differences between animals and humans and the governance of animals, ${ }^{6}$ there is a growing body of work on animals and war. ${ }^{7}$ In the field of the history of emotions major developments originating in work on emotion, religion and politics in medieval and early modern societies have stimulated important studies of the history of specific emotions and their

\footnotetext{
${ }^{3}$ For the concept of 'natural allies', see Richard P. Russell and Edmund Tucker (eds), Natural Enemy, Natural Ally: towards an environmental history of warfare (Corvallis: Oregon State University Press, 2004).

${ }^{4}$ Picture Post, 25 November 1944.

5 John Miller, 'London Zoo and the Victorians, 1828-1859', Cultural and Social History 2015, 12:3, 432434, here p. 434.

${ }^{6}$ Erica Fudge, Brutal Reasoning: Animals, Rationality and Humanity in Early Modern England, (Ithaca, N.Y.: Cornell University Press, 2006); Geoffrey Plank, 'Thomas Tryon, Sheep and the Politics of Eden', Cultural and Social History 2017, 14:5, 565-581; Helen Cowie, Exhibiting Animals in NineteenthCentury Britain: Empathy, Education, Entertainment (Basingstoke: Palgrave Macmillan, 2014); Helen Cowie, 'An attractive and improving place of resort', Cultural and Social History 2015, 12:3, 365-384. ${ }^{7}$ For the role of mules in the British Army during the First World War see: A. Varnava, 'Fighting Asses: British Procurement of Cypriot Mules and their Condition and Treatment in Macedonia', War in History, 23.4 (2016), pp. 489-515; A. Varnava, 'The Vagaries and Value of the Army Transport Mule in the British Army during the First World War', Historical Research, 90.248 (2017), pp. 422-446. For the use of horses by the British and Canadian Armies during the First World War see: J. Singleton, 'Britain's Military Use of Horses 1914-1918', Past \& Present, 139 (1993), pp. 178-203; J. Corvi, 'Men of Mercy: The Evolution of the Royal Army Veterinary Corps and the Soldier-Horse Bond during the Great War', Journal of the Society for Army Historical Research, 76 (1998), pp. 272-84; A. Iarocci, 'On the Threshold of Modernity: Canadian Horsepower on the Western Front, 1914-18', Journal of the Society for Army Historical Research, 89 (2009), pp. 51-64. For the role of horses in German and Japanese forces see: L. DiNardo and A. Bay, 'Horse-Drawn Transport in the German Army', Journal of Contemporary History, 23 (1998), pp. 129-42; J. Boyd, 'Horse Power: The Japanese Army, Mongolia and the Horse, 1927-43', Japan Forum, 22 (2010), pp. 23-42.
} 
expression. ${ }^{8}$ The field has been given impetus by contributions from scholars concerned with the emotional impact of modern war on military personnel. ${ }^{9}$ Human-animal relationships in this context are beginning to receive attention. ${ }^{10}$ Our intervention offers a perspective on the overlooked 'more-than-human' emotional dimensions of the British war effort of 1939 to 1945, as well as exploring an instance in which war reshaped the affective ties between humans and animals.

We use as a central analytical category Barbara Rosenwein's concept of the emotional community. Rosenwein describes an emotional community as comprising individuals 'tied together by fundamental assumptions, values, goals, feeling rules, and accepted modes of expression' who are members of a social group in which they have a common stake and interests. ${ }^{11}$ According to Rosenwein, such groups change over time, define what is emotionally acceptable, and promote emotional norms. We argue that the British soldiers who were required to become muleteers in the Burmese jungle, together with their officers and veterinary personnel, formed such a community, based on a shared idea of a close and mutually beneficial relationship between men and mules. However, the project was fraught with instabilities. Although soldiers' ability to connect emotionally with mules helped bind the community together and provided a way for muleteers to differentiate themselves positively from other soldiers, the material circumstances of jungle warfare constantly threatened the viability of those bonds.

\footnotetext{
${ }^{8}$ William M. Reddy, The Navigation of Feeling: A Framework for the History of Emotions (Cambridge: Cambridge University Press, 2001); Barbara H. Rosenwein, Emotional Communities in the Early Middle Ages (Ithaca, N.Y.: Cornell University Press, 2006); Laura Kounine and Michael Ostling (eds), Emotions in the History of Witchcraft (London, 2016); Claire Langhamer, The English in Love: The Intimate Story of an Emotional Revolution (Oxford: Oxford University Press, 2013); Thomas Dixon, Weeping Britannia: portrait of a nation in tears (Oxford: Oxford University Press, 2015).

${ }^{9}$ See in particular Santanu Das, Touch and Intimacy in First World War Literature (Cambridge: Cambridge University Press, 2005); Michael Roper, The Secret Battle: Emotional Survival in the Great War (Manchester: Manchester University Press, 2010).

${ }^{10}$ Monika Baár, 'Prosthesis for the Body and for the Soul: The Origins of Guide Dog Provision for Blind Veterans in Interwar Germany,' First World War Studies 6 (2015), 81-98; Ryan Hediger, 'Dogs of War: The Biopolitics of Loving and Leaving the US Canine Forces in Vietnam,' Animal Studies Journal 2 (2013), 55-783; A. McEwen, “He Took Care of Me': The Human-Animal Bond in Canada's Great War', in S. Nance (ed.), The Historical Animal (New York: Syracuse University Press, 2015), 272-87; C. Pearson, "“Four-Legged Poilus": French Army Dogs, Emotional Practices and the Creation of Militarized Human-Dog Bonds, 1871-1918', Journal of Social History, 52, no. 3 (2019), 731-760 ${ }^{11}$ Rosenwein, Emotional Communities, 24-5; Barbara H. Rosenwein, "Worrying about Emotions in History," American Historical Review 107 (2002), 842-3.
} 
In our quest to discover the system of feeling that characterised the British muleteers in Burma, we have explored a range of sources. Official training manuals, contemporary publications and press reports contributed in different ways to the definition of what was valuable or harmful to mules and men at war, and offered a language in which the relationship could be discussed. Above all personal narratives produced by British soldiers themselves, such as diaries, memoirs and oral history interviews, indicate 'the modes of emotional expression that were expected, encouraged, tolerated, and deplored' among muleteers and the contradictory feelings that the experience of inter-species dependency provoked. ${ }^{12}$ It is not possible to access the perspective of the mules themselves, but personal testimonies record the feelings of soldiers towards mules, as well as the emotions they attributed to them. We suggest that such sources permit the concept of emotional communities to be expanded to include the material and cultural roles that animals have played in their formation. ${ }^{13}$ We argue that historians of emotions could usefully pay more attention to how emotions stick to animals, and how feelings towards animals help bind humans together. Our study of the militarised emotional community of the British Army in Burma also supports Sara Ahmed's insight that 'emotions do things.' 14 In this instance, soldier-mule bonds enabled often demoralised British forces to fight in a difficult and dangerous environment while being tested to their limits.

British soldiers and their mules formed only one component of the 'multicultural, imperial army' that fought against Japanese forces in Burma. ${ }^{15}$ As Tarak Barkawi has shown, the complexity and diversity of this army, which was composed of Indian, British, Kenyan and other African troops, challenges the notion that the war in the (so-called) Far East was a national struggle between Britain and Japan, and raises

\footnotetext{
${ }^{12}$ The quotation is from Barbara H. Rosenwein (2010) 'Problems and Methods in the History of Emotions' Passions in Context 1, p. 11.

${ }^{13}$ For attempts to write history from the animals' perspective, see Éric Baratay, Bêtes des tranchées: Des vécus oubliés (Paris: CNRS Éditions, 2013); Sandra Swart, Riding High: Horses, Humans and History in South Africa (Johannesburg: Wits University Press, 2010).

${ }^{14}$ Sara Ahmed, "Affective Economies," Social Text 22 (2004): 119

${ }^{15}$ Tarak Barkawi, Soldiers of Empire: Indian and British Armies in World War II (Cambridge: Cambridge University Press, 2017), 1.
} 
questions about the identities, motivations and experiences of this diverse group of soldiers. ${ }^{16}$ Our article is not representative of all those who fought on the Allied side in Burma but the colonial context is important. Human-animal relations in British and other colonies were one of the sites on which colonialists tried to impose, symbolically and materially, their authority over colonized peoples, and assert their supposed superiority. As targets of culling campaigns, vectors of medical anxieties, prized hunting trophies, or essential draft labourers, animals populate the history of colonialism. The intrusions of colonizers encountered varying degrees of adaption, translation, indifference and resistance from the colonized, while colonizers critiqued the supposedly irrational, inefficient and suspect relations of the colonized with animals. ${ }^{17}$ The experience of British soldiers and mules in Burma in World War Two belongs within this history.

In a study of colonial pet-keeping practices in Burma, Jonathan Saha argues that the colonizer-pet bond represented an emotional refuge and a marker of perceived civilization and superiority. He suggests that 'felt encounters with animals-both real and imagined, as well as physical and affective-were a perennial aspect of British colonial culture in Burma.' ${ }^{18}$ Yet, he argues, while British colonialists sought comfort from their pets, they regarded the Burmese population as displaying a disgusting and

\footnotetext{
${ }^{16}$ Barkawi, Soldiers of Empire. See also Kaushik Roy, 'Discipline and Morale of the African, British and Indian Army Units in Burma and India during World War Two: July 1943 to August 1945, Modern Asian Studies, 44, no.6 (2010): 1255-82. On race in the two world wars see, inter alia, Gajendra Singh, The Testimonies of Indian Soldiers and the Two World Wars: between self and sepoy (London: Bloomsbury, 2014); Santanu Das (ed.) Race, Empire and First World War Writing (Cambridge: Cambridge University Press, 2011); Wendy Webster, Mixing It: Diversity in World War Two Britain (Oxford: Oxford University Press, 2018).

${ }^{17}$ On animals in colonial India and Burma, see Rohan Deb Roy, 'Nonhuman Empires,' Comparative Studies of South Asia, Africa and the Middle East, 35/1 (2015), 66-75; Rohan Deb Roy, Malarial Subjects: Empire, Medicine and Nonhumans in British India, 1820-1909 (Cambridge University Press, 2017); James L. Hevia, Animal Labor and Colonial Warfare (Chicago: University of Chicago Press, 2018); Lloyd Price, 'Animals, Governance and Ecology: Managing the Menace of Venomous Snakes in Colonial India', Cultural and Social History 2017, 14:2, 201-217; Mashesh Rangarajan, and K. Sivaramakrishnan (eds) Shifting Ground: People, Animals and Mobility in India's Environmental History (New Delhi: Oxford University Press, 2014); Jonathan Saha, "Colonizing Elephants: Animal Agency, Undead Capital and Imperial Science in British Burma," BJHS: Themes 2 (2017), 169-89.

${ }^{18}$ Jonathan Saha, 'Among the Beasts of Burma: Animals and the Politics of Colonial Sensibilities, c. 1840-1940', Journal of Social History, 48.4 (2015), p. 921
} 
quasi-sexual intimacy in their relationships with animals. Our contribution adds a new layer to understandings of British emotional entanglements with animals in Burma, complicated by the brutalities and privations of jungle warfare. In the relationships that developed between British soldiers and mules kindness and love coexisted uneasily with violence as soldiers sought to defend their masculinity and their military status.

The ethos of kindness

Mules are bound up with histories of colonial combat, far from the centre of famous European military campaigns, before and during World War Two. As a result of British ignorance about the colonial dimensions of the Second World War, the British soldiers who worked with mules felt forgotten at the time and have been largely erased from cultural memory. ${ }^{19}$ Unlike other wartime animals, such as pigeons, deployed near or on the Home Front, the mules themselves were not celebrated with medals and press coverage. ${ }^{20}$ Yet the number of militarised mules grew from only 25 in the Royal Army Service Corps in 1939 to 120,000 across British imperial forces in 1946. ${ }^{21}$ This surprising increase in an age of mechanised warfare is explained by the global reach of World War Two into landscapes deemed unsuitable for modern forms of transport, including areas of France, Italy, Egypt, Syria, Sudan and India, as well as Burma. Mules were purchased both close to these theatres of war and from further afield, including the USA, South Africa and Argentina. ${ }^{22}$ Their increasing numbers required the recruitment of British military

\footnotetext{
${ }^{19}$ Roy, 'Discipline and Morale'; L. Noakes and J. Pattinson, 'Introduction: 'Keep Calm and Carry On': The Cultural Memory of the Second World War in Britain', in L. Noakes and J. Pattinson (eds), British Cultural Memory and the Second World War (London: Bloomsbury, 2014), p. 15.

${ }^{20}$ Pigeons were celebrated in postwar Victory Shows, which were reported in the press. See, The People, 18 November 1945; The Times, 27 November 1945; The Times, 7 December 1946.

${ }^{21}$ RASC History Committee, The Story of the Royal Army Service Corps 1939-1945 (London: Bell and Sons, 1955), p. 542. Hansard Parliamentary Debates, House of Commons, Pigeons and Animals (War Use), 22 October 1946, vol. 427, col. 1452-3

${ }^{22}$ Clabby, The History of the Royal Army Veterinary Corps 1919-1961, p. 40; G. T. Newport, 'A Remount Depot in Italy', Journal of the Royal Army Veterinary Corps, 16.2 (1945), pp. 148-151; R. K.
} 
personnel to work with and care for them. The Royal Army Veterinary Corps (RAVC) was expanded in 1943 and mule mobilisation also entailed the transformation of British soldiers into Animal Transport Officers (ATOs) and mule drivers. ${ }^{23}$ Their numbers were augmented by the officers and men already deployed to work with mules in the British Indian Army as part of the defence of India's north west frontier. But for most British soldiers the first encounter with mules occurred in training. ${ }^{24}$

[Figure 1. British infantry, artillery and service corps personnel training with mules in the Black Mountains, Wales.]

The training of soldiers was based on the control and transformation of their minds and bodies to create fit, orderly and productive troops. ${ }^{25}$ Its objective was to toughen men emotionally as well as physically so as to stimulate aggression towards the enemy and to encourage a killer instinct, a process that David French argues was particularly difficult in the case of British conscripts who were disinclined to hate the bastard who is trying to kill you' ${ }^{26}$ Regimental and company sergeant majors were notorious for using a combination of sarcasm and violence in the context of gruelling training regimes to knock new recruits into shape. Idealised British military masculinity was youthful, tough, loyal and fearless.

Mules, too, were trained to operate effectively in combat, but very different techniques were used where they were concerned. British and Indian army training manuals emphasised that treating mules with gentleness was the only route to

\footnotetext{
Loveday, 'The Transport of Animals by Sea between South Africa and India During World War II', Journal of the Royal Army Veterinary Corps, 18.2 (1947), pp. 54-60.

${ }^{23}$ J. Clabby, The History of the Royal Army Veterinary Corps 1919-1961, (London: J. Allen \& Co., 1963) pp. 33-4; A. Woods, 'The Farm as Clinic: Veterinary Expertise and the Transformation of Dairy Farming, 1930-1950', Studies in the History and Philosophy of Biology and the Biomedical Sciences, 38 (2007), pp. 478-9.

${ }^{24}$ G. Dunlop, Military Economics, Culture and Logistics in the Burma Campaign, 1942-1945 (London: Routledge, 2016), pp. 116-7.

${ }^{25}$ E. Newlands, Civilians into Soldiers: War, the Body and British Army Recruits (Manchester: Manchester University Press, 2014), p. 53.

${ }^{26}$ David French "YYou cannot hate the bastard who is trying to kill you ..." Combat and ideology in the British Army in the war against Germany 1939-45' Twentieth Century British History, 2000, 11:1, 1-22. See also Sonya Rose, Which People's War? National identity and citizenship in wartime Britain 193945 (Oxford 2003). Rose argues that British soldiers exhibited 'temperate masculinity'.
} 
creating effective human-animal working partnerships. ${ }^{27}$ The British Army's pre-war Manual of Horsemastership states: 'Young mules are naturally timid and easily startled, but they are, as a rule, docile and easily broken in, if treated with great kindness and patience. Rough treatment of any kind must be avoided as likely to prove fatal to successful training. ${ }^{28}$ Stereotypes characterised mules as obstinate and violent, but the training manuals depicted them as intelligent, docile, hardworking and amenable animals that only became 'vicious' through ill treatment. ${ }^{29}$ The term 'breaking in' may have had connotations of violence but it was intended to be a gentle process. ${ }^{30}$

Personal testimony provides insights into how 'breaking in' mules worked in practice. Philip Malins, a wartime British ATO with the Royal Indian Army Service Corps (RIASC), recalls how un-broken Argentine mules were treated at an animal training establishment in Jullundur in India. The objective was to accustom the mules to being groomed, clipped, saddled, shod and loaded. But Argentine mules' allegedly poorly-controlled breeding, subsequent branding, and rough handling during transportation, meant that their initial experiences of humans were primarily violent so they were prone to kicking and biting on first encounter. ${ }^{31}$ Army trainers were told to win their trust through patience and kindness. ${ }^{32}$ Working on the assumption that 'the way to its heart is through its stomach', a mule was initially touched from a distance with a 'blob stick', which was an eight-foot long pole that was padded and had fodder placed on the end. Trainers would gradually move closer, and as the

\footnotetext{
${ }^{27}$ These training manuals appear to have been used in conjunction, as they frequently crossreference each other. Tarak Barkawi notes that the basic training and battle drill of the Indian Army was similar to that of the British Army, albeit adapted to the cultural idiom and educational standards of Indian recruits. T. Barkawi, 'Culture and Combat in the Colonies: The Indian Army in the Second World War', Journal of Contemporary History, 41.2 (2006), p. 347.

${ }^{28}$ War Office, Manual of Horsemastership, Equitation and Animal Transport 1937 (London: HMSO, 1937), p. 140. See also India Army General Staff, Royal Indian Army Service Corps Training, Vol III, Transport, 1938 (New Delhi: Government of India Press, 1938), p. 98.

${ }^{29}$ Varnava, 'The Vagaries and Value of the Army Transport Mule', 422-446; India Army General Staff, Royal Indian Army Service Corps Training, Vol III, 71.

${ }^{30}$ India Army General Staff, Royal Indian Army Service Corps Training, 71-2. India Army General Staff, Notes on Animal Transport: Military Training Pamphlet No. 29 (India) (New Delhi: Government of India Press, 1938), 1-3.

${ }^{31}$ P. Malins, 'The Indian Army Transport Mule', in B. Nicholls, P. Malins and C. MacFetridge (eds), The Military Mule in the British and Indian Army: An Anthology (Solihull: The British Mule Society, 2000), 53-4.

32 India Army General Staff, Royal Indian Army Service Corps Training, Vol III, 96.
} 
mule's suspicion decreased and confidence grew the trainer would progressively touch it all over, culminating in handling its legs, the most sensitive part of its body. ${ }^{33}$ Through such patient and gentle tactile encounters mules were 'broken in' and the foundations of the relationship between mules and British soldiers were laid.

If practicing gentleness was the keynote of breaking in, the expectation of kindness towards mules pervaded later training too and became a norm around which the British muleteer emotional community developed. The Army Remount Department had overall responsibility for preparing mules (and horses) for war and the animals in training were known as 'remounts'. ${ }^{34}$ The Manual of Horsemastership referred mainly to the horse and the mounted horseman but its instructions applied equally to pack animals and muleteers, for all that they were at the less glamorous end of the spectrum. ${ }^{35}$ It taught men to prioritise the care and management of their animals before looking after themselves. The Manual stated the importance of being a good horsemaster should be impressed on every mounted soldier. He should be taught to look upon his horse as his best friend, to study it, to take a pride in its appearance and to look after its wants before his own. ${ }^{36}$ Ronald Nappin, a muleteer with the Welsh Regiment who served in India and Burma, remembers the extra responsibility this placed on muleteers, in comparison to other soldiers: 'whenever you stopped or wherever you came to, the animal always came first - you fed and brushed your animal before yourself. ${ }^{37}$ Routines of personal cleanliness and pride in appearance were used to promote military discipline in soldiers. So, too, muleteers were taught to regard the health and appearance of their animals as an expression of their own soldierly competence. ${ }^{38}$ Putting the needs of their animals before

\footnotetext{
${ }^{33}$ Malins, 'The Indian Army Transport Mule', 53-4.

${ }^{34}$ Sally Hoult, 'Making Horses for War: the Army Remount Service,' National Archives Blog, August 2017, https://blog.nationalarchives.gov.uk/making-horses-war-army-remount-service/, accessed 31 January 2020.

${ }^{35}$ Great Britain Army Veterinary Service, Animal Management 1923, p. 313. On the glorification of the horse in an earlier period see Karen Raber, Animal Bodies, Renaissance Culture (Philadelphia:

University of Pennsylvania Press, 2013).

${ }^{36}$ War Office, Manual of Horsemastership, 1.

${ }^{37}$ Ronald Henry Nappin, Interview, 29 August 2000, IWM 20593/2.

${ }^{38}$ Newlands, Civilians into Soldiers, 61.
} 
themselves became a habitual practice within the British muleteer emotional community.

\section{Violent contradictions}

Kindness and consideration towards mules vanished, however, in situations in which soldiers felt threatened. Training manuals stressed that the 'golden rule' in handling remount mules was for the soldier to be completely confident: 'Any sign of nervousness is fatal. A nervous man makes a nervous animal. No nervous men should be allowed near remounts. ${ }^{39}$ The British muleteer emotional community was, in theory, comprised of calm and steadfast men. But mules provoked anxieties. Ivan Daunt recalled the difficulties of loading mules, especially when they kicked out, and remembered that handling mules 'took a long time to get used to.' ${ }^{40}$ Similarly, Frederick Holloman recalled that he and the other men in his unit did not initially like the mules due to their kicking out. ${ }^{41}$ The fear of being kicked led some muleteers to ignore the ethos of patience and gentle handling and to retaliate. Anthony Emms recalled that a veterinary officer complained about finding cuts and bruises on the legs of mules, which were the result of soldiers kicking back at the animals during grooming. ${ }^{42}$ Experience of the strength and unpredictability of the mule challenged the ideal of the muleteer who would always prioritise its well-being.

This tension was exacerbated by the fact that many mule drivers lacked previous experience of working with animals. An article in The Times about a Transport Animal Training Company in Scotland stated that the 'best recruits' for the service were former drivers of horse artillery, followed by milk rounds-men and other men experienced in working with transport horses. Men accustomed to 'superior racing stables' seldom took kindly to the 'inferior' task of pack transport, and farm labourers were described as having no flair for the role. ${ }^{43}$ Yet muleteers came from a

\footnotetext{
${ }^{39}$ India Army General Staff, Royal Indian Army Service Corps Training, Vol III, 98.

${ }^{40}$ Ivan Decourcy Daunt, Interview, 7 March 2000, IWM 20461/10.

${ }^{41}$ Frederick Charles Holloman, Interview, 6 December 1995, IWM 16348/1.

${ }^{42}$ Anthony Charles Emms, Interview, 3 March 2001, IWM 20578/4.

${ }^{43}$ The Times, 25 September 1942.
} 
range of working-class occupational backgrounds many of which involved little or no contact with transport animals. Mules were used in Burma in particular by the 'Chindits', Special Forces led by General Orde Wingate, who were recruited from the Indian and British armies to penetrate behind Japanese lines for the purpose of sabotage. Each of the eight columns that made up these forces included 57 mule handlers. Many of the British muleteers had previously belonged to the King's Liverpool Regiment and came from the 'smoky industrial areas of Northern England' where 'they were born and bred to town and factory life. ${ }^{\prime 44}$ An officer from the Chindit campaigns later recalled that in many cases the muleteers had never touched a mule or pony before in their lives when they took over the animals. ${ }^{\prime 45}$

To help inexperienced officers and soldiers overcome their fears, they were given physical tasks intended to instil confidence in approaching and handling the animals. Philip Malins completed an eight-week intensive course in animal transport at Lansdowne in the Himalayas before becoming an ATO. He described how British and Indian soldiers were forced to crawl under the legs of the mules, were required to catch mules in a paddock without halters, and also played tug-of-war mounted on mules. ${ }^{46}$ Competitive team events were widely used in British army training as a way to inculcate 'team spirit' and promote collective discipline. ${ }^{47}$ In muleteer training mules were framed as team players: their involvement in sports in partnership with soldiers was constitutive of the emotional community of men and mules.

Not only British soldiers' but also mules' anxieties had to be countered. Most were unaccustomed to violent warfare, and, according to the Army Veterinary Service's 1923 guide, their 'one drawback from a military standpoint is their liability to stampede under fire.' ${ }^{48}$ To train mules to tolerate battle conditions they were forced to swim across rivers, embark on and disembark from boats, and march in circumstances in which soldiers simulated military engagements. These included

\footnotetext{
${ }^{44}$ C. J. Rolo, Wingate's Raiders: An Account of the Incredible Adventure that Raised the Curtain on the Battle for Burma (London: George G. Harrap and Co. Ltd, 1944), p. 32.

${ }^{45}$ Quoted in Clabby, The History of the Royal Army Veterinary Corps 1919-1961, p. 133.

${ }^{46}$ Malins, 'The Indian Army Transport Mule', pp. 55-8.

${ }^{47}$ Newlands, Civilians into Soldiers, p. 66.

${ }^{48}$ Great Britain Army Veterinary Service, Animal Management 1923 (H.M.S.O: London, 1923), p. 313.
} 
rattling tins full of stones behind handfuls of fodder to ensure that mules would eat in loud combat conditions. Mules were also forced to pass repeatedly under a simulated dive bomber - a fairground-type swing which swung backwards and forwards just skimming the mules' backs - to ensure that they kept on marching even if planes flew low overhead. ${ }^{49}$

However, mules had one natural faculty that could not be countered by training: their call. The noise a mule makes usually begins with a horse-like whinny and ends with a bray similar to that of a donkey. It can be loud and prolonged. Braying mules might alert the enemy in the relative silence of the jungle, jeopardising covert operations like those undertaken by the Chindits. This possibility led to a form of institutionalised violence against mules, organised by the military hierarchy. A British Army laryngologist developed a de-vocalising procedure which involved placing mules under general anaesthetic and completely excising their vocal chords, with the 'speaking sinew' cut adrift by half an inch. ${ }^{50} \mathrm{~A}$ total of 5,563 mules enrolled in Special Forces operations were subject to the operation with 43 deaths. ${ }^{51}$ However, the devocalising procedure was not always effective. Some mules regained their 'voices' during military operations to the acute anxiety of the troops..$^{52}$

The practice of de-vocalisation highlights tensions in the ethos of kindness and interspecies teamwork between men and mules in the muleteer community. It exposes not only a lack of trust in mules' reliability as partners in warfare but also the Army's view of mules as potentially expendable experimental casualties. Military anxieties about mules' ability to thwart objectives and to put soldiers at risk led to the

\footnotetext{
${ }^{49}$ Malins, 'The Indian Army Transport Mule', pp. 53-4; India Army General Staff, Royal Indian Army Service Corps Training, Vol III, p. 99; Mules in Combined Operations Paper (22 February 1945), Mules in Combined Operations (Jan 1944 - Aug 1945), National Archives, London, War Office Papers (hereafter NA, WO) 203/3542.

${ }^{50} \mathrm{C}$. M. Stewart, 'The Muting of Animals for General Wingate's Force Operating Behind the Japanese Lines in Burma', Journal of the Royal Army Veterinary Corps, 17.3 (1946), 87-92; A. J. Moffet, 'Medicine and War: The Silent Chindit mules', British Medical Journal, 287 (1983), 1946-7.

${ }^{51}$ Clabby, The History of the Royal Army Veterinary Corps 1919-1961, p. 124.

52 Stewart, 'The Muting of Animals', 91; Clabby, The History of the Royal Army Veterinary Corps 1919$1961,125,138-9$.
} 
perpetration of extreme and sometimes lethal violence towards mules, contradicting the valorisation of gentleness within the muleteer emotional community.

Inter-species affection

The depth of these violent contradictions is the more apparent in view of the emphasis placed on bonding in muleteer training, and the affection that developed between men and mules on military operations. Training practices encouraged soldiers to study the individuality of their allocated animal. Military guides stated that 'animals require the same care as men, and the same things affect their efficiency and their comfort. Study your animals; get to know their individual needs and peculiarities, treat them properly and they will serve you well. ${ }^{53}$ Manuals advised that soldiers and mules should be 'correctly suited to each other' and stressed that individual soldier-mule partnerships should not be broken up unless it was unavoidable. ${ }^{54}$ Such guidance paralleled that on soldier-dog pairings developed at the British War Dog Training School. ${ }^{55}$ Mules, like dogs, were represented less as interchangeable military technologies and more as respected individuals within interspecies partnerships.

The ability to establish and maintain bonds with mules was central to the values of the muleteer emotional community. T.W. Sams, a British officer in the RIAVC, wrote that the main aim of his training course at Poona (now Pune) Veterinary College was 'to develop a close relationship between animal and driver'. ${ }^{56}$ Likewise Frank Turner, an ATO in the second Chindit campaign, attested to the primacy of cultivating an 'affinity' between soldier and mule during training. ${ }^{57}$ The memories of muleteers highlight the importance of both oral and tactile encounters to this end. ${ }^{58}$ Percy Routledge, a muleteer in the second Chindit campaign, believed that his mule

\footnotetext{
53 India Army General Staff, Notes on Animal Transport: Military Training Pamphlet No. 29, p. 92.

${ }^{54}$ War Office, Manual of Horsemastership, pp. 191-2, 1.

${ }^{55}$ R. Kirk, 'In Dogs We Trust? Intersubjectivity, Response-able Relations, and the Making of Mine Detector Dogs', Journal of the History of Behavioural Sciences, 50.1 (2014), 8.

${ }^{56}$ Private Papers of Captain V.P. Sams, 13166, Memoir, Imperial War Museum, London, p. 10.

${ }^{57}$ Francis William Geoffrey Turner, Interview, 19 September 1991, IWM 12260/1.

${ }^{58}$ Soldiers were encouraged to speak frequently to their mules. India Army General Staff, Notes on Animal Transport: Military Training Pamphlet No. 29, 3.
} 
learned to recognise his voice and responded to the specific ways he touched his neck. ${ }^{59}$ Anthony Emms recalled that gradually a 'rapport was established between mules and men,' which was exemplified by men holding onto the tails of their mules for support when trudging up hills. ${ }^{60}$ Frederick Holloman recalled that after his initial dislike and fear of mules, he 'loved them at the finish' ${ }^{61}$

The British muleteer community was, however, diverse, and the training itself, as well as the uptake of the values it was designed to instil, was uneven. Major Frank Turner noted in his wartime diary that, during training, an ATO 'grew from an untrained horseman to a groom, farrier, vet, teacher, authority on loads and even a mule-driver when necessary. ${ }^{62}$ But other accounts indicate that, in practice, the length and quality of training varied. Dominic Neill, an ATO officer in the first Chindit expedition in 1943, recalled that, in spite of being charged with the considerable responsibility of overseeing a column of muleteers, his training was rudimentary. He received little guidance beyond a lecture by the Brigade Veterinary Officer about the welfare of mules and how to exercise, groom and feed them. Following this, he remembers being 'left to get on with it ourselves - quite honestly, we did not know whether we were looking after the mules well or not. ${ }^{63}$ While some ATOs and muleteers understood and practiced the routines of animal management advocated in training and forged bonds with their animals, others did not.

Successful bonding, however, paid dividends in terms of physical and emotional comfort that helped men to cope in extreme circumstances. ${ }^{64}$ Ronald Nappin recalled being forced to hide from a passing Japanese column in the jungle. To try to

\footnotetext{
${ }^{59}$ Percy Nicholson Routledge, Interview, 1 November 1995, IWM 16269/2 and 3.

${ }^{60}$ Anthony Charles Emms, Interview, 3 March 2001, IWM 20578/4.

${ }^{61}$ Frederick Charles Holloman, Interview, 6 December 1995, IWM 16348/1.

62 Transcript of an account written by Major F Turner in August 1944, Private Papers of Major F Turner, 3994, Wartime Diary, Imperial War Museum, London, p. 4. This is the same Turner who was interviewed by IWM in 1991 (see note 57).

${ }^{63}$ Dominic Fitzgerald Neill, Interview, 10 August 1993, IWM 13299/1.

${ }^{64}$ On other attempts to cope emotionally with combat, see Das, Touch and Intimacy; Roper, The Secret Battle; On animals as sources of emotional comfort, see Pearson, "Four-Legged Poilus"; McEwen, 'He Took Care of Me', pp. 272-288; Swart, 'Horses in the South African War', 348-366; S. Maenpaa, 'Sailors and their Pets: Men and their Companion Animals aboard early Twentieth-century Finnish Sailing Ships', The International Journal of Maritime History, 28.3 (2016), 480-495.
} 
calm his mule and keep her quiet, he stroked her nostrils. ${ }^{65}$ Other muleteers also communicated with their mules via touching or blowing into their nostrils, imitating the ways in which mules communicated with one another. ${ }^{66}$ Men remembered these tactile forms of cross-species communication as methods of pacifying their animals, but they also alleviated their own stress. One officer recalled how the jungle at night could play on your nerves, especially when you were tired and overwrought, so that a snapped twig seemed like an advancing platoon' ${ }^{\prime 67}$ and soldiers' war-strain was further compounded by the increasing brutality of warfare against the Japanese. ${ }^{68}$ Soothing caresses were acts of comfort that benefited both man and mule in a cultural and material environment that was physically and mentally draining for British soldiers and severely limited the potential for sentimentality and intimacy. They were seen within the emotional community as healthy responses to the wartorn environment. In contrast, British colonialists had earlier treated physical closeness between Burmese people and their animals as repulsive. ${ }^{69}$

[Figure 2, 'British troops rest with their mules after crossing the Chindwin River near Sittaung in Burma, 17 November 1944']

Mules provided support in more mundane situations too. They alleviated the discomfort of the jungle floor when resting. Geoffrey Button, a soldier on the second Chindit expedition, remembered that 'if you were lucky you managed to curl up with a mule with your head on its belly.' 70 John Masters, the British novelist, took this further. An officer in the Indian Army, he served with the Chindits behind enemy lines in 1943-44, becoming commanding officer of the $111^{\text {th }}$ Indian infantry brigade. ${ }^{71}$ In a memoir of his experiences of the war in Burma he wrote of 'Maggie',

\footnotetext{
${ }^{65}$ Ronald Henry Nappin, Interview, 29 August 2000, IWM 20593/2.

${ }^{66}$ Charles Clarence Stadden, Interview, 27 January 2000, IWM 20010/5; Richard Waterhouse Hilder, Interview, 27 September 1999, IWM 19599/2.

${ }^{67}$ W. F. Jeffrey, Sunbeams like Swords (London: Hodder and Stoughton, 1950), 60.

${ }^{68}$ T. Barkawi, 'Peoples, Homelands, and Wars? Ethnicity, the Military, and Battle among British Imperial Forces in the War against Japan', Comparative Studies in Society and History, 46.1 (2004), 136.

${ }^{69}$ Saha, 'Among the Beasts of Burma.'

70 Geoffrey Clover Button, Interview, 10 June 1997, IWM 17471/2.

${ }^{71}$ Trevor Royle, 'Masters, John (1914-1983),' Oxford Dictionary of National Biography, 21 May 2009, https://doi-org.liverpool.idm.oclc.org/10.1093/ref:odnb/31421
} 
a mule who achieved fame among muleteers. Masters described his own affectionate relationship with her:

although I am not unduly fond of animals except cats, more than once I found myself, at night, hugging Maggie round the neck, stroking her and whispering into her ear what a good, brave, clever girl she was... beautiful, too, I would add, remembering her sex. She snickered coyly. ${ }^{72}$

Masters' anthropomorphism turned Maggie from the sterile hybrid that, as a mule, she was biologically, into a female fantasy figure who responded to his advances. Emma Vickers has argued that physical same-sex, but not necessarily sexual, intimacies were a common feature of British military life during the Second World War. ${ }^{73}$ Mules offered similar opportunities for close corporeal relationships, echoing in a different context the reported intimacy felt by British colonialists towards their pets. $^{74}$

Mules could also be sources of support in military encounters. In contrast to anxieties about them stampeding under fire, and the fears that led to the devocalisation of mules, former muleteers recalled their confidence in animals who stood steadfastly and safely by them in extreme circumstances. W.H. Warren, commander of an RIASC mule company, wrote home about the behaviour of a mule under attack:

The other day we were caught by unexpected mortar-shell fire. One of our boys was wounded and let go the reins of his mule; but the mule, although hit in the leg itself, remained stock still until, on my noticing it was unattended, another driver took over. Don't let anyone tell you the mule is stupid. He's the most intelligent beast imaginable! ${ }^{75}$

Warren believed that this intelligence and 'the mules' admirable quality of steadiness under fire' underpinned the affection the drivers developed towards them. ${ }^{76}$ Other testimonies offer similar memories of mules' 'dogged endurance', even when they were wounded or injured. In particular, mules frequently developed

\footnotetext{
72 J. Masters, The Road Past Mandalay (London: Cassell Military, 2003 [1961]), 215-6.

${ }^{73}$ E. Vickers, Queen and Country: Same-Sex Desire in the British Armed Forces, 1939-1945

(Manchester: Manchester University Press, 2013), 53-6.

${ }^{74}$ Saha, 'Among the Beasts of Burma.'

${ }^{75}$ Private Papers of Major V H Warren, 15527, Memoir, Imperial War Museum, London, 26.

76 Ibid., Appendix 1.
} 
severe sores (known as galls) from being overworked, overloaded and underfed. ${ }^{77}$ Dominic Neill spoke of the mules as the 'heroes' of the Chindit expeditions: 'they marched and marched and marched' while their galls were so severe that they smelt like 'rotting corpses' ${ }^{78}$

Mules gained the status of talisman in some battalions. Frank Turner recalled that Maggie, beloved of John Masters and a 'leader amongst the mules', served as a mascot and a representative of the men and mules under his command. Visiting dignitaries would meet Maggie, having heard the stories about her exploits that circulated through the British imperial forces, and she became a source of pride for the battalion..$^{79}$ In other circumstances men were reluctant to let sick mules go for fear of bringing bad luck on the platoon. Charles J. Rolo, journalist and author of a wartime account of the Burmese campaigns, described such incidents during the first Chindit expedition. In retreat, an officer called Thompson, the column leader, had great difficulties with his mule, Yankee, whose physical condition had significantly deteriorated. Yankee frequently slipped into deep pools of water and held up the speed of the column. Rolo described how other officers wanted to leave Yankee behind, but

Thompson firmly refused, insisting that a seasoned mountain artillery mule was worth his weight in gold. Secretly he had come to look upon Yankee as their good luck symbol, their talisman against disaster. Yankee had travelled with them every step of the way; he had survived the jungle and the Japs, hunger and thirst, river-crossings and mountain ranges. Somehow, Thompson felt, his future and theirs were linked. So long as Yankee stayed with them they were indestructible. ${ }^{80}$

Superstitious beliefs and the adoption of mascots were not uncommon practices among service personnel during the Second World War. They were servicemen's attempts to exercise human agency in situations in which they had limited control

\footnotetext{
77 Private Papers of Captain T W Groves, 15160, Memoir, Imperial War Museum, London, 2-3; Walter Purcell 'Scottie' Scott, Interview, 27 November 1991, IWM 12352/4.

78 Dominic Fitzgerald Neill, Interview, 10 August 1993, IWM 13299/2.

${ }^{79}$ Francis William Geoffrey Turner, Interview, 19 September 1991, IWM 12260/6.

${ }^{80}$ Rolo, Wingate's Raiders, 116.
} 
over the future. ${ }^{81} \mathrm{~A}$ talisman mule, such as Yankee, provided soldiers with a psychological resource for coping in extremely precarious situations.

Testimonies that eulogise the mules for their displays of courage, determination and stoicism suggest that the confidence of soldiers in their animals was greatest when the mules displayed the human characteristics of the soldier hero. As brave and stoic fellow combatants, mules strengthened muleteers' sense of themselves as determined and tough soldiers. They were also remembered as life savers. Frank Turner recalled that Maggie carried an injured officer for days until they reached medical support. ${ }^{82}$ Men understood that their lives were tied to those of their animals and, in recalling their experiences years later, recorded their appreciation and gratitude: 'I know we couldn't have done it without the animals'83; 'the mule was the whole key to everything' ${ }^{84}$; and 'the mules were our God-send.' 85

\section{Casualties of War}

Thousands of mules, however, became casualties of war, succumbing to gunshot wounds, starvation, gall problems and diseases such as surra, an infection of the blood causing fever, weakness and death. ${ }^{86}$ The deteriorating health of mules led to anxiety and grief amongst British soldiers so that alongside the practice of kindness and the celebration of stoicism, the muleteer community was marked by more troubling emotions.

There was an uneasy tension between mule management and the demands of warfare, laden with anxiety, guilt and strain. ATOs had special responsibility for retaining as many mules as possible for supply and operational purposes, so the mules' health was of particular practical concern. Philip Malins reflected on the dilemma of having to keep his column moving while not giving the mules time to

\footnotetext{
${ }^{81}$ MacKenzie, 'Beating the Odds', 382-400.

${ }^{82}$ Francis William Geoffrey Turner, Interview, 19 September 1991, IWM 12260/6.

${ }^{83}$ Ronald Henry Nappin, Interview, 29 August 2000, IWM 20593/2.

${ }^{84}$ Francis William Geoffrey Turner, Interview, 19 September 1991, IWM 12260/1.

${ }^{85}$ Herbert Stephen Harwood, Interview, 18 September 2000, IWM 20769/8.

${ }^{86}$ Clabby, The History of the Royal Army Veterinary Corps 1919-1961, 133-141.
} 
recover from the galls and open wounds on their backs. He wrote, 'it was a good job mules could not speak or show pain like humans... I felt like a murderer loading mules in such condition. ${ }^{.87}$

The deteriorating condition of mules affected soldiers' morale. David Halley wrote that, after their first engagement with Japanese soldiers, members of the King's Liverpool Regiment were afflicted by a 'general nerviness' worsened by the ailing condition of their horses and mules. Ten horses had to be put down and he described the mules as 'in a sorry state, gone at the knees, and badly galled. ${ }^{188}$ As the condition of the mules worsened, soldiers made drastic attempts to keep them alive and moving, even though they too were suffering:

Our rations were non-existent, and we lay down tired and hungry. But not before we had given every possible attention to our one remaining mule. This was now a sorry sight. Bamboo as a sole diet did not seem to agree with it, and its galls were bad. It was bandaged with field dressings, bandages, four by two, and other odds and ends, and even had a puttee wound round its fore leg. It could not have been more carefully groomed if it had been due to step into the ring in the morning. ${ }^{89}$

Mules and soldiers were joint victims of lack of food and long marches in the jungle environment. At times the only option was to leave mules in the jungle, or to slaughter them, but this caused great unhappiness among the men. The journalist Rolo described the moment when a Burmese soldier was forced to relinquish his mules for slaughter at the end of the first Chindit expedition: 'All night he talked to them, caressed their heads, and prayed in a low monotone. At dawn he vanished into the jungle until it was all over. Afterwards he wept for three days. ${ }^{\prime 90}$

Rolo did not describe British soldiers weeping in such a way, in a narrative inflected by a tradition of imperial writings that portrayed the Burmese as particularly physically and emotionally close to animals and which sought to differentiate

\footnotetext{
${ }^{87}$ P. Malins, 'The Indian Army Transport Mule', 68.

${ }^{88}$ D. Halley, With Wingate in Burma (William Hodge: London, 1944), 78-9.

89 Ibid., 115.

${ }^{90}$ Rolo, Wingate's Raiders, 130-1.
} 
between British and Burmese relationships with animals. ${ }^{91}$ But British soldiers expressed dismay in their own accounts of abandoning animals. Some recalled anxiety at the prospect of what would happen to their mules, fearing that they would be slaughtered at the end of hostilities or fall into the hands of the Japanese whom they perceived as cruel to animals. ${ }^{92}$ Not wanting to leave their mules in Burma, they pressed the Army to secure them passage back to India. ${ }^{93}$ Many muleteers achieved the bonding advocated in training and their feelings of affection were enduring: recalling the final separation from their mules provoked discomposure in narrators fifty years after the event. ${ }^{94}$ Emotional attachment to the mule as a close companion in war contradicted the military necessity of seeing it, at the end of the war, as an expendable military adjunct.

The tension between the mule as comrade and as military property was explicit in accounts of mules being euthanised. Sometimes this was represented simply as a merciful act. Frank Stewart wrote that mules suffering from shrapnel and bullet wounds could have been saved if they had been evacuated to a veterinary hospital, but the circumstances of the Chindit expeditions meant that many such mules were put down. ${ }^{95}$ In other circumstances, such as the retreat to India at the end of the first Chindit expedition in 1943, mules were killed because they might impede the movement of men. Rolo described in grim detail how this was done. A senior officer acted as executioner, ordering a soldier to strip naked and hold the animal's head while the officer cut the mule's carotid artery: 'There was an appalling surge of

\footnotetext{
${ }^{91}$ Saha, 'Among the Beasts of Burma.'

92 Private Papers of Major V H Warren, 15527, Memoir, Imperial War Museum, London, 36; Dominic Fitzgerald Neill, Interview, 10 August 1993, IWM 13299/4.

93 Joseph Stretton, Interview, 5 September 1995, IWM 15740/2; Geoffrey Clover Button, Interview, 10 June 1997, IWM 17471/3.

${ }^{94}$ Dominic Fitzgerald Neill, Interview, 10 August 1993, IWM 13299/4. For the concept of 'discomposure' in life narratives see P. Summerfield, "Dis/composing the Subject: Intersubjectivities in Oral History' in T. Cosslett, C.Lury and P. Summerfield (eds.) Feminism and Autobiography: Texts, Theories, Methods (London: Routledge, 2000), 93-108.

${ }^{95}$ Clabby, The History of the Royal Army Veterinary Corps 1919-1961, 137-8.
} 
blood. The naked man stood up - a monstrous figure drenched in blood from head to foot. Veterans of three years of war slipped off, nauseated, into the jungle. ${ }^{\prime 96}$

Not only were mules killed for the sake of military mobility, they were also repositioned as a form of human sustenance in the testing conditions of the Burmese jungle. At the end of the first Chindit expedition, slaughtered mules became meat for soldiers. This retreat was particularly strenuous for the surviving soldiers, who had been behind enemy lines for over three months. They faced torrential monsoon rain and were frequently under attack, while suffering sickness and exhaustion. Rolo related how the retreating soldiers were constrained to slaughter and eat their remaining mules over a period of six days. The few horses they had with them were eaten on the seventh day. ${ }^{97}$

John Masters offered an account that strained to justify the practice in technical language. Over a period of 110 days during the expedition the soldiers faced a dietary deficiency of 800 calories a day, due to supply problems, and each man lost between 30 and 40 pounds in weight. ${ }^{98}$ Mules faced similar problems becoming increasingly lame. Dispatching these animals, and eating them, Masters argued, provided much-needed calories for men. The draught energy they provided as transport animals was re-appropriated as calorific energy for soldier bodies.

The consumption of mules, however, was not only a physical act. As Rachel Duffett highlights, in any circumstances the act of eating for soldiers went beyond calorific concerns, bridging the needs of body and psyche. ${ }^{99}$ But for British soldiers eating mule or horsemeat broke a cultural and symbolic taboo, and this was compounded by the bonds that muleteers had formed with their animals. ${ }^{100}$ Even if mule meat could provide physical and mental comfort, eating it placed a strain on soldiers at

\footnotetext{
${ }^{96}$ Rolo, Wingate's Raiders, 129-130. For similar reactions to dead horses by veteran British officers in France during 1940, see, M. Alexander, 'War and its Bestiality: Animals and their Fate during the Fighting in France, 1940', Rural History, 25.1 (2014), 117.

${ }^{97}$ Rolo, Wingate's Raiders, 130.

${ }_{98}$ Masters, The Road Past Mandalay, 275-9.

${ }^{99}$ R. Duffet, 'A Taste of Army Life', Cultural and Social History, 9.2 (2012), 254.

${ }^{100}$ C. Otter, 'Hippophagy in the UK: A Failed Dietary Revolution', Endeavour, 35.2-3(2011), 86.
} 
the time and retrospectively. Joanna Bourke argues that British and American soldiers in twentieth-century wars differentiated between legitimate and illegitimate killings of enemy combatants and civilians as a way of maintaining their sanity and insulating themselves against feelings of agonising guilt. ${ }^{101}$ Dispatching mules was, of course, different from killing humans, but narrators used similar strategies, seeking to legitimise such executions as both a military necessity and an act of mercy, and sometimes exonerating themselves. ${ }^{102}$ Turner recalled that he killed only lame mules for meat for hungry soldiers, while stating that, as a vegetarian, he did not eat it himself. ${ }^{103}$ Neill selected only the 'sickliest' mules to be butchered but nevertheless said that he felt like a 'brute', and added that the meat was unpleasant and that, after the first meal, he never ate it again. ${ }^{104}$

\section{Conclusion}

To wage war in the mountainous jungles of Burma, British military leaders enlisted mules to transport essential supplies, weaponry and ammunition. They also had to recruit and train Animal Transport Officers and mule drivers to manage these vitally important creatures. The British soldiers involved found themselves in roles that were far from those to which glamour and an aura of military masculinity attached in World War Two. ${ }^{105}$ Compared with the fighter pilot, the captain of a destroyer, or a commando, the muleteer seemed to belong in an almost pre-modern world. Within the British Imperial Forces those who worked with mules could be beleaguered. Other soldiers drew on stereotypes of the stubborn and bad tempered mule to mock muleteers, who were widely assumed to have had their two front teeth knocked out by their charges. ${ }^{106}$ However British ATOs and muleteers drew strength from each other and from their animals, building an emotional community focused on an ethos

\footnotetext{
$101 \mathrm{~J}$. Bourke, An Intimate History of Killing: Face-to-Face Killing in Twentieth-Century Warfare (London: Granta Books, 1999), 229.

102 For an examination of the conditional status of militarised dogs utilised by the US armed forces in the Vietnam War, see, Hediger, 'Dogs of War,' 55-73.

${ }^{103}$ Francis William Geoffrey Turner, Interview, 19 September 1991, IWM 12260/2.

${ }^{104}$ Dominic Fitzgerald Neill, Interview, 10 August 1993, IWM 13299/3.

105 See, for example, Martin Francis, The Flyer: British Culture and the Royal Air Force 1939-1945 (Oxford: Oxford University Press 2008).

${ }^{106}$ Michael Gifford Dent, Interview, 8 June 2000, IWM 20361/1.
} 
of kindness and care that contrasted starkly with mainstream military values. Dependent upon their animals for survival in the harsh conditions of the jungle, British soldiers formed bonds with mules that they remembered with feeling late into their lives. In recording and recalling them, they unintentionally reproduced British narratives and practices of seeking comfort in animals from the earlier colonial period in Burma.

The emotional community that developed around mules and men was fraught with instabilities. The process of learning to work with mules was beset with obstacles: mutual fear led to reciprocal violence, be it trading kicks or, more devastatingly for the mule, forcibly removing one of its faculties, its 'voice'. Men were taught to trust their mules through familiarity and physical training. But the unnatural world of warfare pressed hard on both sides of the partnership, particularly the mule, which had to be inured to horrific battle conditions that men had the capacity to understand, intellectually at least, as a means to an end.

The intense affection that British muleteers remember developing for stoic and steadfast animals who appeared devoted to them, and whom they treated with respect and gentleness, was the more poignant in view of the suffering that war inflicted upon the mules. Human love was, presumably, small compensation for galls and lameness. Above all, slaughtering mules for food was a massive betrayal of the system of feeling idealised in the muleteer community. The ultimate irony of using animals to wage war is symbolised by the consumption as food of the creature that the muleteer had been taught 'to look upon ... as his best friend'. The positive emotions of the inter-species relationships that developed in the jungles of Burma were profoundly contradicted by the deadly situations in which animals and men were placed in the cause of victory. 


\section{List of captions}

Figure 1

Lieutenant Taylor, 'The British Army in the United Kingdom', War Office Second World War Official Collection, H 11151, Imperial War Museum, London, http://www.iwm.org.uk/collections/item/object/205197620 [accessed 6 February 2020]

Figure 2

No 9 Army Film \& Photographic Unit, 'British troops rest with their mules after crossing the Chindwin River near Sittaung in Burma, 17 November 1944', War Office, Central Office of Information and American Second World War Official Collection, SE 533, Imperial War Museum, London, http://www.iwm.org.uk/collections/item/object/205205093 [accessed 6 February 2020].

\section{Acknowledgements}

We would like to thank Susan Grayzel for her comments on a draft of this article. This research was funded by an AHRC North West Consortium Doctoral Training Partnership PhD fellowship awarded to Tom Webb 